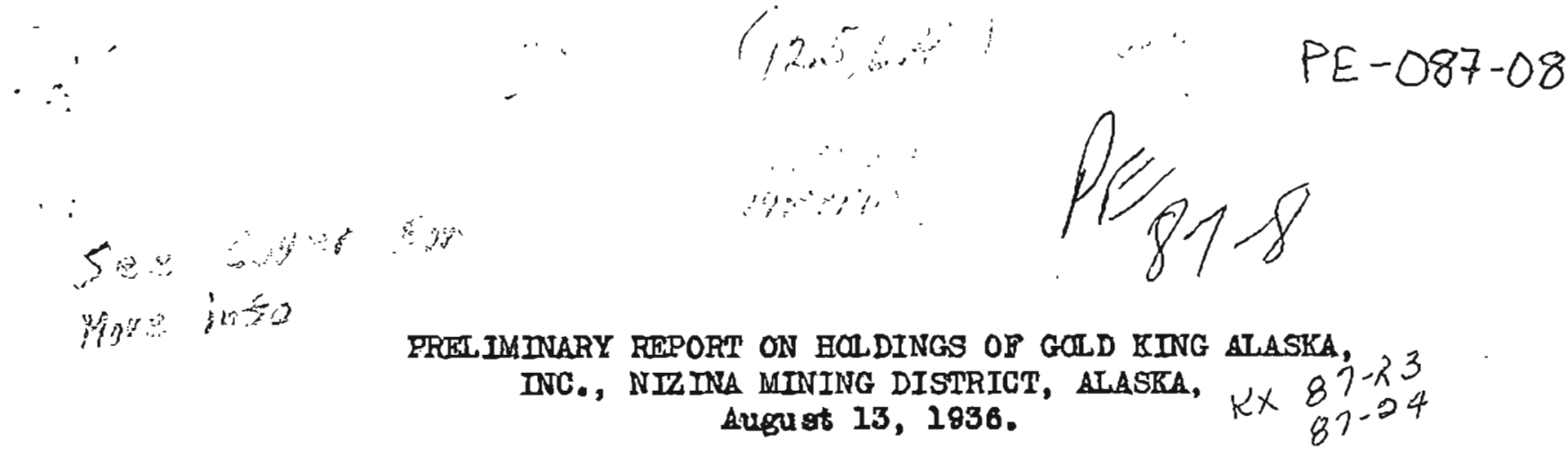

Location and Acoossibility:

The property held by the Cold KIng Alegka, Inc. conslate of 87 ola1ms and 1s loceted on the restern slope of Wlillems Peak in central N1zina district. The claims extend from lower camp on the MeCarthy-Dan Creek road at the 17-mile post, east up the slope to an elevation of 6400'. The showings are located near the top of the peak between elevations of 5880 and $6400^{\prime}$. Th1s locetion 18 approximately 2 m1les in a atralght line south of the Dan Creek placer camp. To reach this property the road from MeCarthy to Dan Ereok is followed to the 17-mile post. In surmer this road is maintained in a falr condition for automoblles by the Alaska Road Comisgion. The cost of auto hire is 10 each way to Dan creak. From lower camp, elevation of naarly 2200', a horse trall has been built up the 91 de of the mountala a distence of 3 to 4 miles to upper camp, elevation 5240'. The upper camp consists of a 16x24' tent and a small rock cabin and occuples a falrly level position on a bench in a small glacial pocket. A trall along the slides from camp leads up the mountain to the rorkings. The last $2000^{\prime}$ of horse trail Is steep and makes traveling wh horses dangerous due to $1009 \theta$ slide rook.

\title{
Histary and Ornars:
}

Th1s property was ataked in 1930 by J. W. Berret and conststed of 7 lode clgims and called the cold King. Barret clalms the origlnal discovery kforever, a short crosscut tunnel near the veln shors erldence of former work. This tunnel 13 lown as the kruhm tunnel. Information as to the year this tunnel ses started, together with any account ritten regarding alscovery prior to 1830 , is lacking.

In May, $1932 \mathrm{M}$. M. Reese visited this property and a copy of bis report is held on flle. This property pas referred to as Gold King Mines. Reege returned in Maroh, 1933 and sampled the tunnel work completed stnce hia pialt in May the year before. Reose acquired half intereat in the property and Barret held the remaining helf. In 1935 the Gold KIng Alaska, Ino. lawa. The cap1talizetion was 10,000 aheres at one dollar par velue. The total shares vere transferred to Vencouver and the Alaske cold King Mines, Ltó. was organized under Britiah columbia lara, authorized capitalization of two mililon ahares at 50 conts per value. F. R. 
MeDonald 16 progident, J. F. Barret, Vice presldent and M. M, Resse, managing drector. The office 18475 Howe strest, Vancouver, B. C. Inciuded in the group of 27 claims are a fer placer bench claims held elong the face of Williams Peak adjolning the lode olsims. Th1s seevon the property was exantned by $N$. C. Delloune of Vancouver. The lode ahowings were sesampled and the placer holdings invertigated. This examination had just been completed on the date of the miter's visit, and no one repreanting the company was present on the property on this date. As a result some of the showings on the property were not seen.

\section{Geology and Showinge:}

The general geology of this district is contained in $U$. 9 . G. 8. Bulletin No. 448 , Geology and Mineral Resources of NiElna District, Llaska," by Moffit and Capps, and Bulletin No. 675, "Dppor Chitina Valley, Alaske" by Moffit and Overbeck. The formations of Willams Peak are referred to as Kennesott formation whieh consist of sheles, sandgtones and conelomerete infeh contain quartz dlorlte, a Jurasic Intrusivo. The morintain Itsalf represent $\mathrm{a}$ a secment of a IImb of a great synclinal fold. Its present existence as a mountaln is due to a central graititic stock that has metamorphosed the surrounding eediments making a reater degree of hardness that has withotood the erosion effecta of Bevere lce and water action. Thla granite is exposed a few hundred feet east of the showings at an elevation of 8000 ' In the small glactel clrque, and it 1 s exposed for a length of $500^{\circ}$. The monntain top contains a fer mall remuants of overlying limestone which 1s underlain with shales and argillites contalning thin beds of quartzito. Many contact phases are present about the granite stock and later granitoid alkes cut the flak-1ylng sediments in a north to northnest alrection.

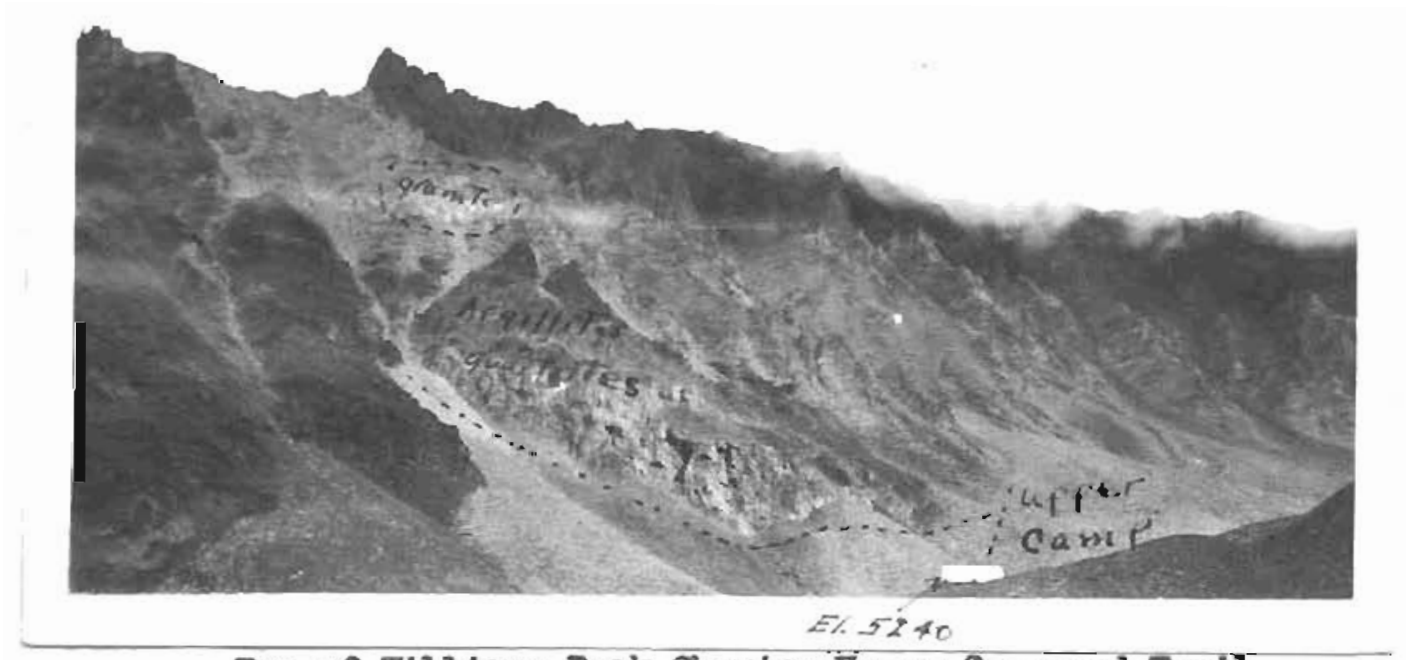

Top of Willitans Peak Showing Upper Camp and Trall, Grantte atock and Mlat-lying Freilliten with Interbanded Quartaites. 
The waln showing consists of a small persistent vela in a shear zone. Th1s veln was triced orer 800' and reported traceable on the east alde of the glaclal elrque a distance of $2000^{\prime}$ to $3000^{\prime}$. The north side of the peak is inaeassible due to ateep biuffs. The erposad portion of the rain exists between elevationg of $5880^{\circ}$ and $6400^{\prime}$ to within a fow feet of the top. Small outeropplngs of parallel velns containlng a different mineralization were noted between tho otibnite vein and the granite stock over a distance of $400^{\prime}$ to $500^{\prime}$. Favelopment has been conflned to the stibnite vein whiah consist of three tunuels with several rock euts and trenches. No.1.8 tunnal or lowar tunnol (Noto position on following photo) 18 located at an elevation of 5880'. It was driven on the vein and has a length of 74' (Note eccompanjing sketch).

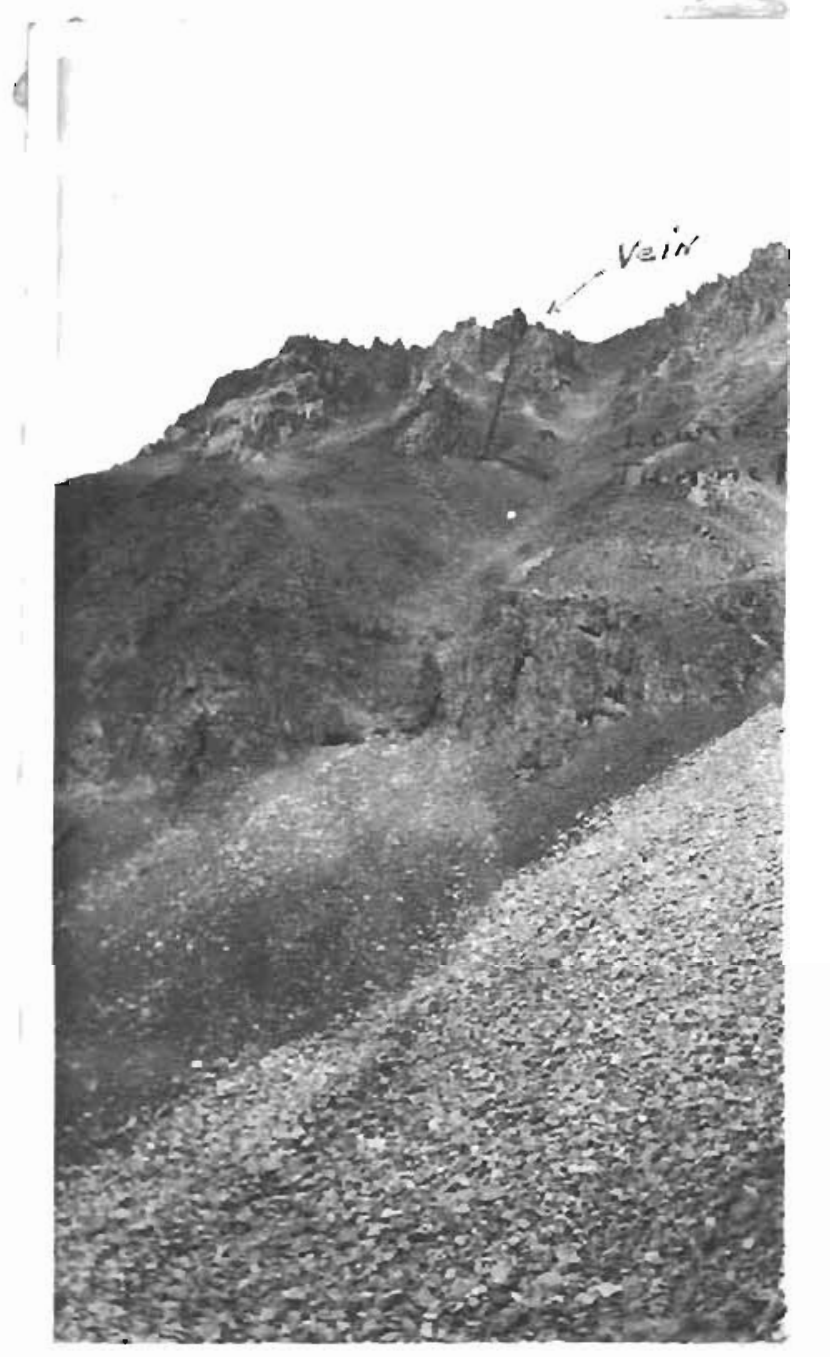

Position of cold=Antimony Vain Aerogs Top of Will lame Peak, Locally Known as Gold King, Bl. $5880^{\prime}$ to B400'. 
It strike is N. $28^{\circ}$ to $30^{\circ}$ F. and aipe $76^{\circ}$ to $78^{\circ} \mathrm{ST}$. The hanging

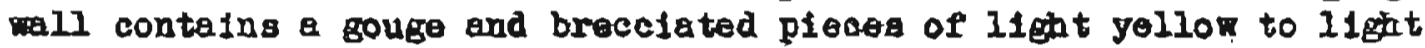
greenish color wioh regembles a highly altered dike which hes a width from a fow 1pohes to 81. The rein consists of a bighly altered and mineralized shear zono. This zone conteins a sall band af quartz that conteins a congiderable amount of atibnite. This otibnite vein varies from 2 inchos to a widh of $8^{\prime \prime}$ and 10 expoged for a distance of 40" in the tunnel. The sheared mall rock $1 \mathrm{~s}$ deofdedly altered and most of the mineralization is oxidized. It varles in 71 dth from 1 to 2 ' on each gide of the quartz. Two channel samples were taken (Note sicetoh and assy shert).

No. 3 tunnel at an elevation of 6280 date of visit due to the adit being filled rith ice. It mas reported to be nearly 200' In length and followed the vein. The dump ahowed the. same cheracterlstic altered alke and mell rooks with pleces of quartz and stibnite six to eight inches in width botween walls. An outcrop at the top of adit showg $6^{n}$ of altered dike material on the hengwil

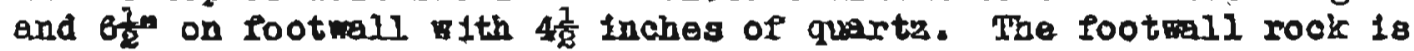
a amail granitold dike mess. Two semples were teken at this point (Note essay shoet).

Fo. 2 tunnel located Bl. 6190' and 50' east of No. 3 is an old tunnel erosscut tonnel of earlier date. It was driven to out the stibalte rein at a depth of 40 to $50 \%$. It laoks a fer feet of intersecting the vein, however, a fer emall gas veinlets and blebs of questz with alight mineralization vere encountered.

The vein outerops in several trenches and rook cute above No. 3 tunnel to Ithin a couple of hundred feet of the top. The quartz and Btibnite bend varfos from 4 to $\theta^{\prime \prime}$ in width and the malls are more or less altered as noted in the tunnel. Various phases of metamorphosed gediments and dike mses are cut along 1ts course. One chennel sample of the quartz (Note assay gheot) ras taken 100' above No. 3 tunnel.

Cenerally this veln may bo olaseed as a flosure veln wh a little horizontel morement. It cuts through shales below, then argililtes ond quartzites and numorous granitold dikes shoring a meh later origin than the granite atock to the enst. It parallels a light yellor colored dike that also cuts through the above mentloned gediments and granitic dikes. This dike containg abundent feldepar, is porphyritic and appears very muah like a monzonite dika. Between the dike and stibnite vein are small veing containing realgar and orpiment. It is the bellef of the writer that both types of relag are associated ath the later monzonite (?) difo. 


\section{Minerallzation:}

The infneralization in the relas represent two types and both carry gold and a I1ttlo silver. The stibnite is oonfined to the quartz band and carries the bighest gold values. The pyrite with its oxidized prodncts is inly in the ltered wall rock, gouge and al tered dike marial. The pyrite erystals are medium to fine while the stibnite crystels are medium to lerge and have an interlooking etructure. Stibnite cryatals litn long and $\frac{1}{4}$ wide vere noted. The quartz is finely cryatalline and contalng numerous ill rugs which are lined with protruidng eryatal faces having the eppearance of a quartz geode. Both the large stibnite cryatels and numorous quartz orystals represent a long alow perfod of growth and formed under lor cryatallization temperatures. Occastonal small spocks of realgar and opplmant were noted associated with the stibnite. Calcite, and other ilme contact minerals w contained in the altered wil rook, the greoniah dike minerals and the quartz make up the gangue minerais.

The smaller veins seen contalned realgar and orpiment in a gouge of quartz, calcite and other lime contact minerals.

The development thus far accomplished has been done by hand methods, and periodically. Whter conditlons are severe due to high - levetions and steop slopes covered rith snow. Heter is scarce during summer months, a small amount belng found by digging into the talue alides. Timber and wood are lacking, but found below 3000' elevation.

The amount of amples taken are not sufficlent to arrive at an average velue for the vein. They do show value in gold from 0.14 to $0.72 \mathrm{oz}$. per ton, and 1 ts presence both in altered wall rock and aosoolated with the atibnlte, the amount of antimony and general representetion of widths. One factor to beer in mind 18 the technioal problems encountered in treating this ore. 


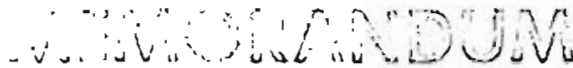

io:

FROM:
James A. Williams

Director

Division of Mines and Minerals

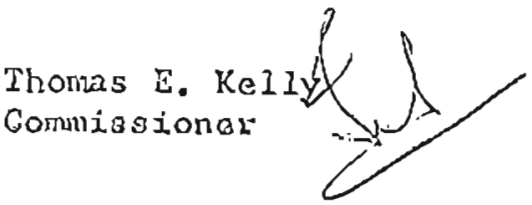

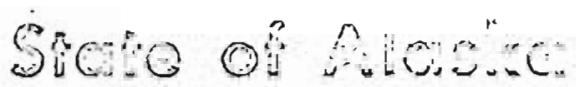

DEPARTMENS OF NATURAL RESGURCI:S

DATE I May 34, 1968

SUBJECT,

Local Service Road

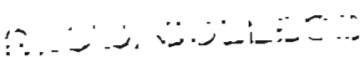

$\because \because \frac{\ddots}{\because} \because \because \vdots$

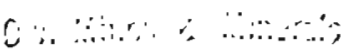

Georga Gizberitún

Yesterday, a Mr. George Gilbertson, a prospector from the McCarthy area, visited my office seeking assistance in the construction of a local service road to his claims on Dan Creek near McCarthy. Although there are no funds appropriated to implement Senate Bill 636, I was interested in the story he had to tell about the potential gold, silver, and copper deposits on his property. I agreed to send one of our mining engineers to inspect his claim and furnish us a report, after which, if favorable, we would try to help. him out in some manner.

Prior to the start of the field season, I would like for one of your engineers to plan a short trip to visit Mr. Gilbertson's prospect. As I understand it, a mail plan leaves Chitina on Monday morning at 10:00 a.m. for the May Creek Airport. Passenger rates are $\$ 7.50$ opposed to $\$ 100$ aircraft charter. I suggest that you contact Mr. Gilbertson by mail in care of May Creek Airport, Alaska; so that he may be available to furnish ground transportation to his claims.

If there is any substance to his story, and if the claims warrant intensive investigation, I may be able to interest a large independent company in coming into Alaska to attempt to participate in his venture. You may be familiar with Mr. Gilbertson and have some other background on his capabilities. If so, please advise.

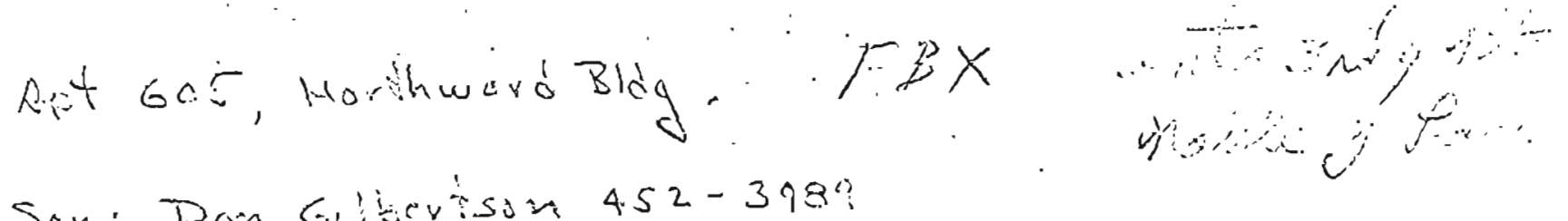


ASSAY SHETT, SAMPLE TAKEM ON PFOPERTY OF GOLD KTHC ALASKA, RNC.

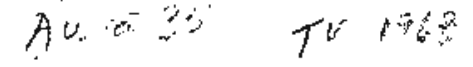

Senplo

No.

48

49

50

\section{No. 1 lower tumnel 50'}

from adit, beck of drift, BI. $5860^{\circ}$.

No. I lower tannel, free of tunnel, $74^{\dagger}$ from adit; 퍼. $5880^{\circ}$.

Surface outcrop 100' above No. 3 tmning, B. $6320^{\circ}$. adef of No. 3 Outcrop at 901 tunnel,

Same as Fo. 51, footwall and hangingwall.

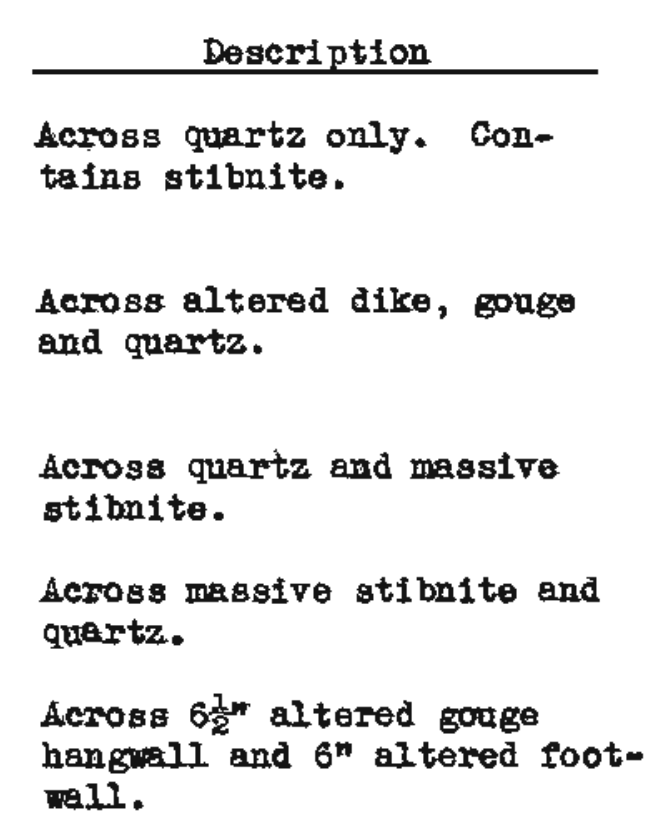

Width $\quad \begin{gathered}\text { Oz. Per Ton } \\ \text { cold } \\ \text { S1lver }\end{gathered}$

0.3

$\operatorname{Trces}$

34.

85.2

None 


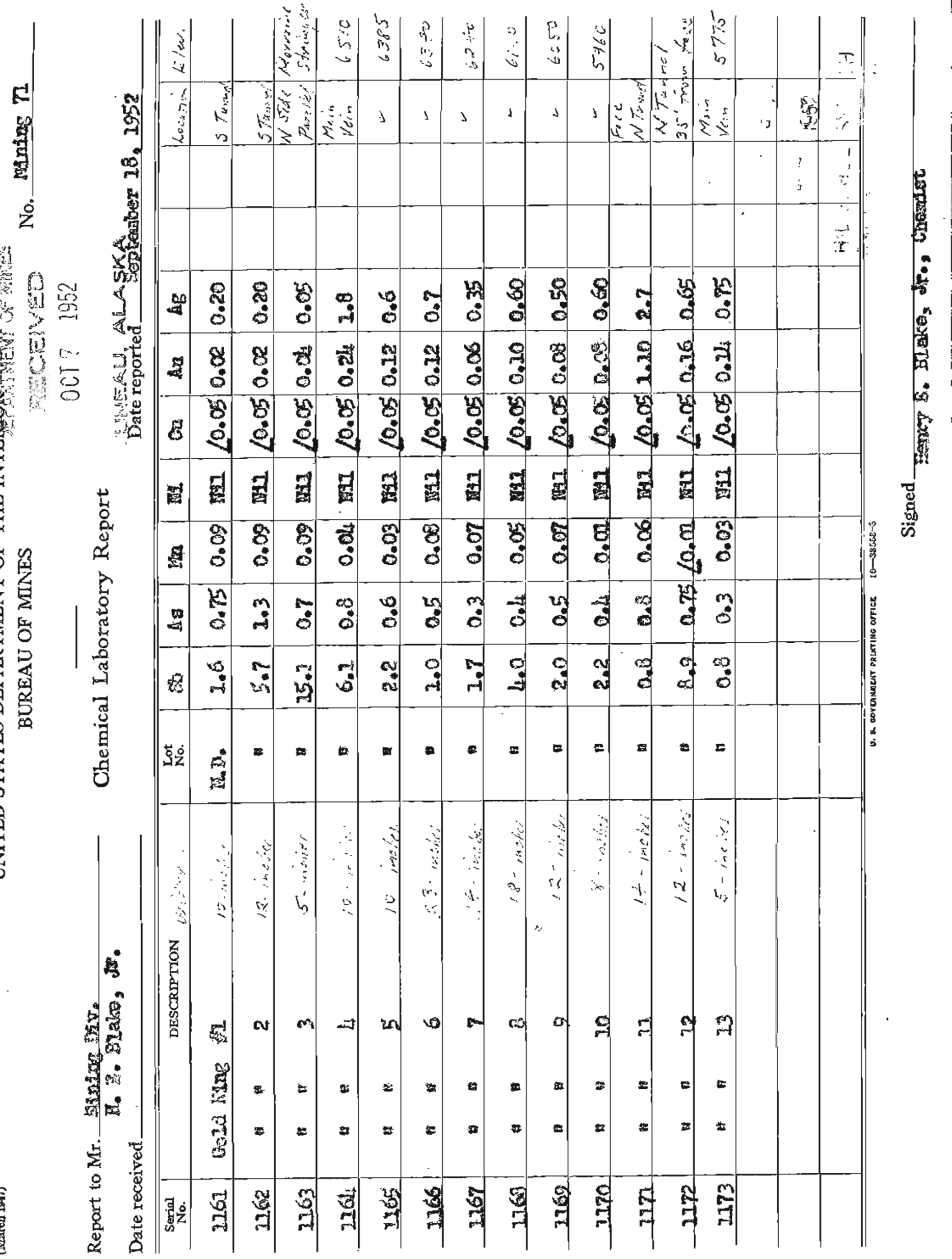


Dis $\quad 1938$

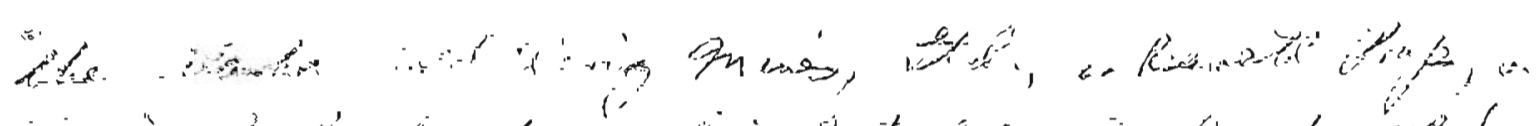
"y.

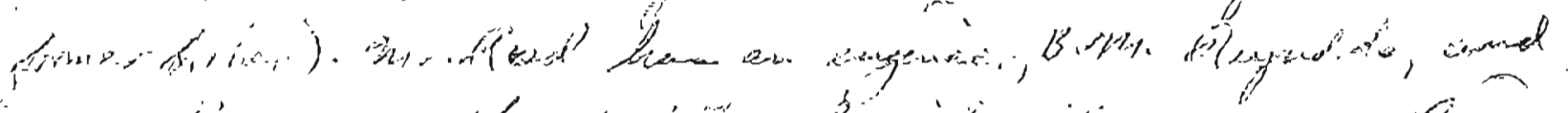

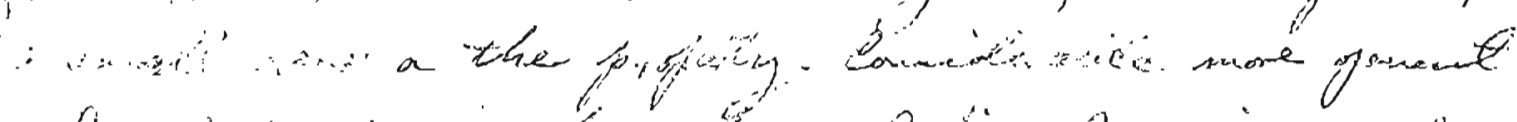

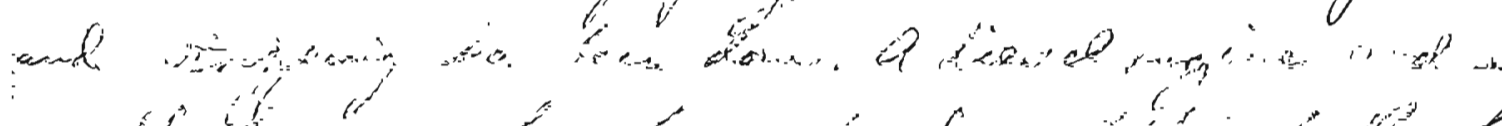

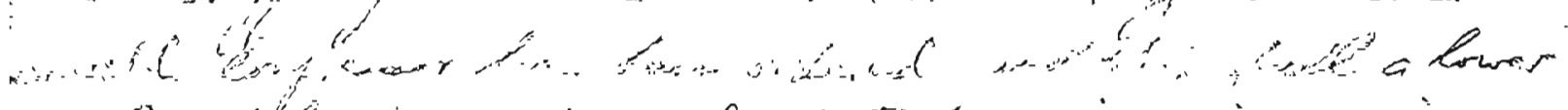

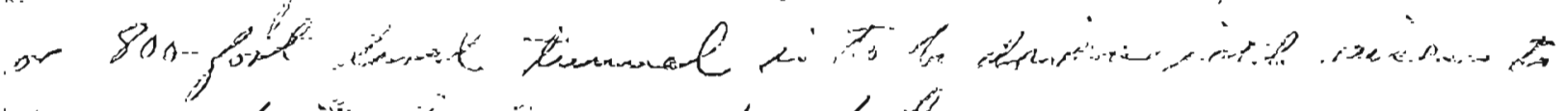

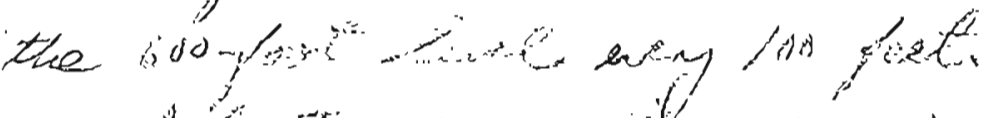

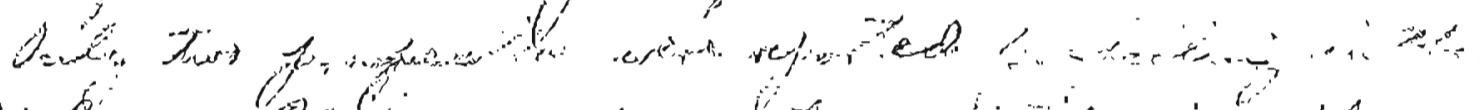

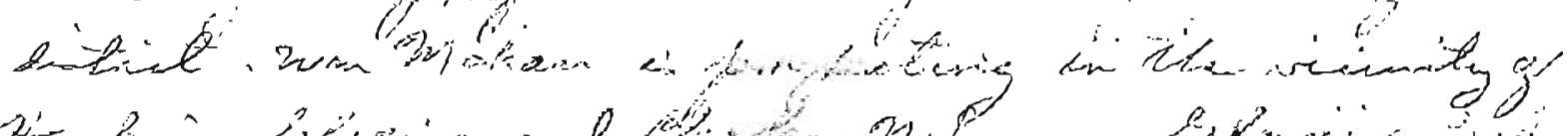

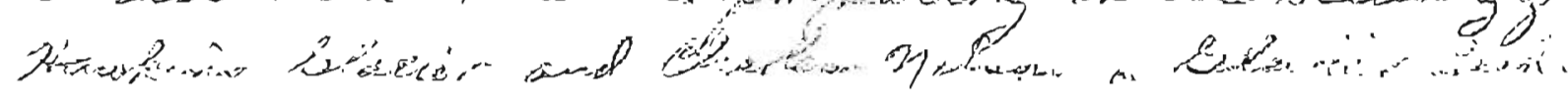




\section{Sketoh \\ Lawer Túnel \\ GOTD KTMO ALASKA INC: \\ WIILAm's Poak \\ Nizina lanirg Distriot \\ Bataka}

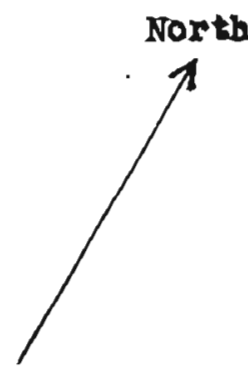

Acrosa quartz vein only. Back of drift.

Nitath. 8"

Gold 0.54 oz. Per Ton Silver 0.10 oz." " Antimong .3 Poroent.

Sheared \& Altered Argillitos

48' to Granitold Bike

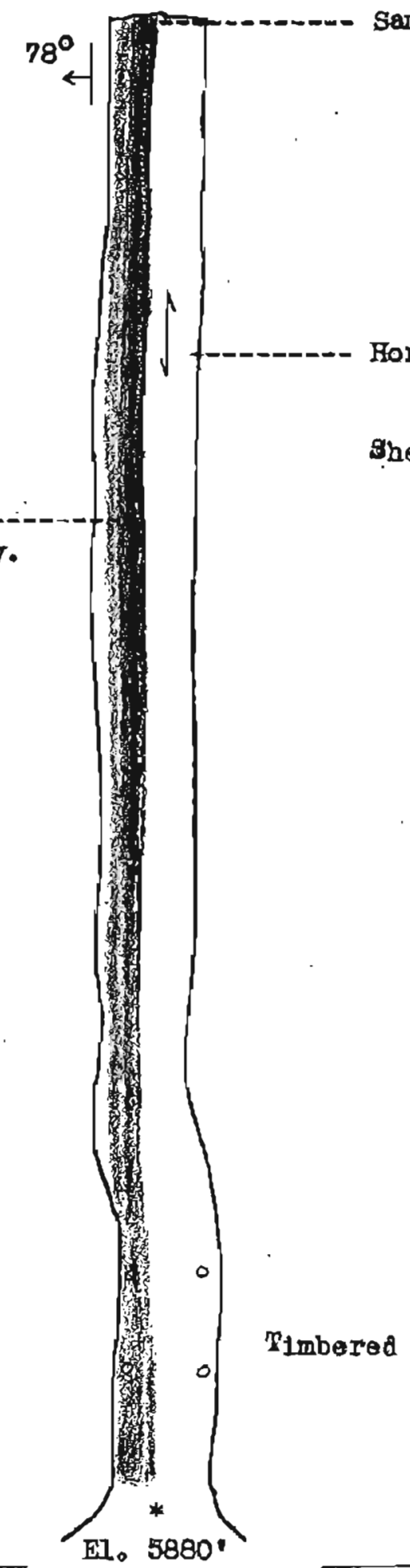

Sample No.48. Acroas Altered Dike, gougo \& quartz.

Width. 17"

Cold 0.84 oz. Per Ton

Hliver $0.20 \mathrm{oz}$." " Antimony Trace.

Forlzontal Movement Along Flsouro.

Iheared \& Altered

Arg1111 to

4 Quartz StIbnjte $V_{\text {eln }}$

DI Sheared \& Mneralized Well pook

(0x1d1zed)

altered $D_{1 k e}$ Materials (Lime Nature).

300' to Porphyss bike 


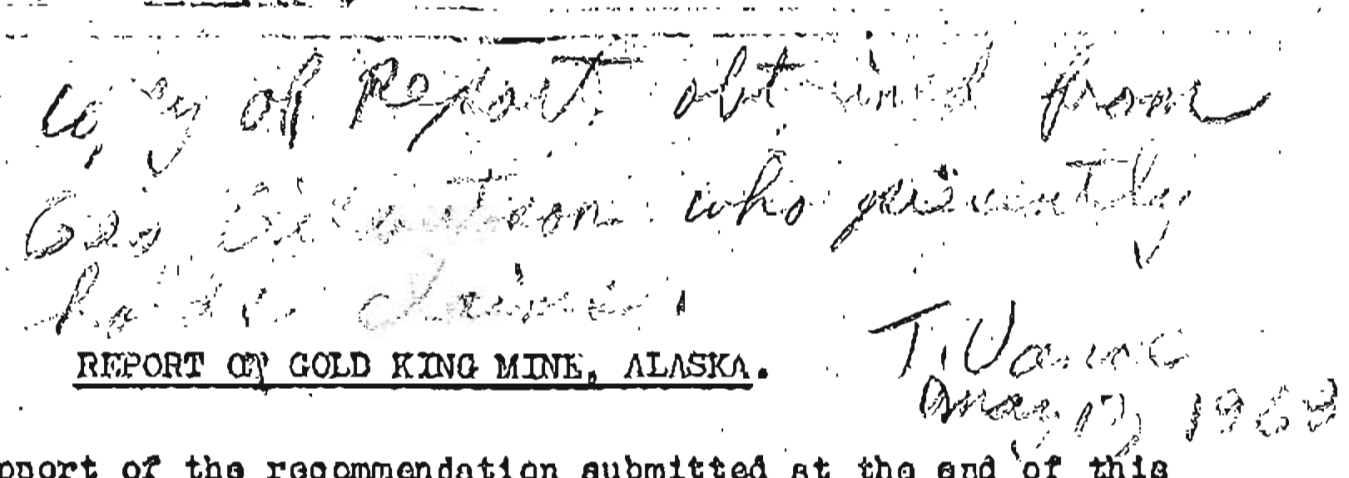

In support of tho rooommendation aubmitted at the and of this report. I end giring a short aynopala or tho rasulta or ray investigution of tho Gold King M1no.

I loft Seattio on April 30th, and arrivod on tho property May 14th. I gpent nine daya w1tis Mr. Rooge and Mr. Mitaholl on tho propertg; oxumining and sampling the veln, and doterninirg tho loostion for tunnelo, m1lielto and tram srom tunnol to millelto. Wo lost Mocarthy May 2.7th, and arr lvod in Sobtilo Juno lat.

The representatione of the owner of the cold King Mino, John 5 . Barrett, wore not only borno out in detall, but in somo robpooto my indings exooedid my experditition. Tho voln is ranerkablo and unueuel in 1 ts persiatence and coninuation. The width on tho south alono verlos from 12 lnohes to 25 lnohos, and averagas

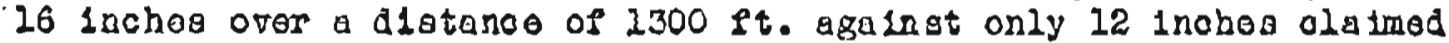
by the ovmer. The vein appeare on the north slde of tho samo charaoter but was inacoesalblo for campling on acoount of stoepnese. A how sy streak of antimony avoraging $13 / 10$ 1nobee runs thru the ositar of the vein fer its ontiro length.

PROVIN TONIMGE:

The tonnago was elgured in blooks of 200 foot vortioal to a dopth of 800 feot. The ore shuto ot this depth 101750 soet long. Th1s Elyeg a tonnage at this lovel of 81,852 tons whioh compares with 83,000 tons ostimeted by the ormor to the $1000 \mathrm{ft}$. Level. In esdition there is probeble ore to the extent of double this amount below tho 800 Pt. level as tho vela oontinueg to lengthon to at legst 2000 Pt.

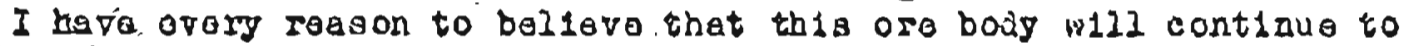
great dep th due to poralstanoe and continuity of the veln.

\section{TALUES:}

I took 28 aumplas thioh havo beon aesayod by Propoanor doroy

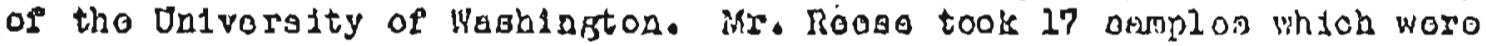
agsayed by Talkenburs \& Co., comeralal aggayers of Seatilo, ard ohookéd by propossor coroy. Thelve of MT. Roeso's amplos woro taken Irom ldentioel pleoes where I emplod. Therofore, in these 12 pleaug wo haye duplioate sampling and asgays in triplicate. To our surpriso the returns of the absays ohow extraordinary variation not only of my semples againat Mr. Reose's amplos egsayed by Profosgor

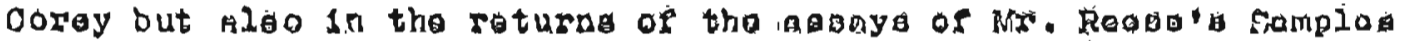
ug Profoseor Corey oompared with those by Falkenbure \& Co.

Vy highoat sumplos, asusylne; 393.60 should havo boon 1antionl with Roora'a aumplo asjayod by Profeasor Corey $\$ 217.20$, and by

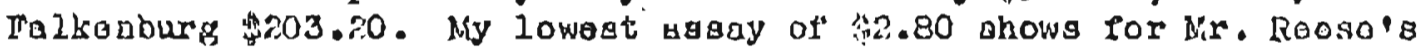

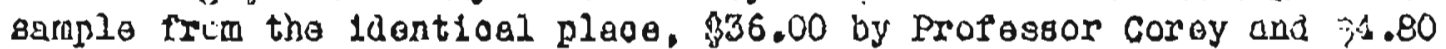
by Felkenburg. Finere I obtaloed 32.60 , Re日se shows Propessor Corey and $\$ 63.20$ by Palronbure, where I show $\$ 57.60$ obtalnod $\$ 8.80$. 



$$
\therefore \quad \text { PQgO } 3 .
$$

returne of the mine.

I rooonroend that part of the rolousod furds of \$2000. bo usod for oxponoor in connootion with tho proposed alll toota. Suab exponoos ohould not exoood s1250. Tho balanoo would bo aratlublo as oupltil after aodepturoo of the property.

I muko tho abova resommandatlono beosuse I an not satispion With the eesty results duo to no pault of tho neseyers, and I roll that the mill teats will show the truerecovorubje eold content or tho oro. If we gtoy where we ure now, wo will not know whother this property is or is not a mile. If tho teste show Pavorablo, then wo heve a propltable mine with long 1150.

$$
\begin{aligned}
& \therefore \text {. . Respootsulzy auboltted. }
\end{aligned}
$$

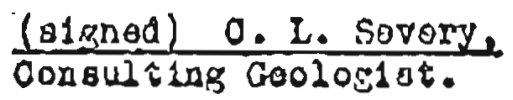

Soattle, Mashiagton. Jane 5, 2832 . 
Copy of assays made by Prof. Corey Assayers U. of $W_{v}$

Juno 4th, 2932

C. L. Servery Samples of ore Cold King properties

Sample

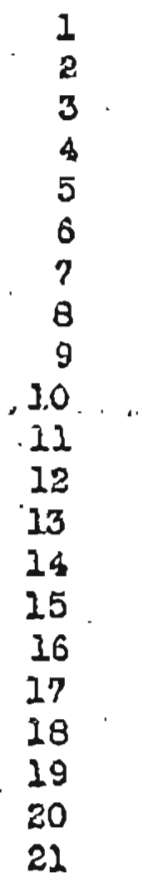

Oz. Gold

0.50
4.28
0.34
0.38
0.14
1.64
0.46
0.68
1.14
1.38
0.18
2.88
1.06
0.32
0.42
0.74
0.16
2.04
0.68
0.90
0.34

Value 20.00 per ron

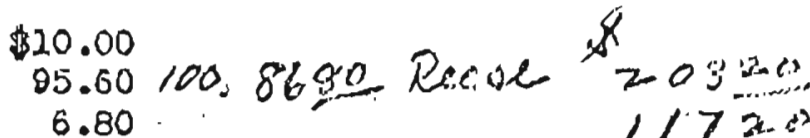

$$
\begin{aligned}
& 117 \frac{38}{80} \\
& 2.80 \\
& 32.70 \quad \text { s }
\end{aligned}
$$$$
9.20890 \text { ReEd. }
$$$$
112 \div 20
$$$$
22.80
$$$$
114 \div 00
$$$$
57.60
$$$$
21.20
$$$$
6.40
$$$$
8.40
$$$$
14.80
$$$$
\begin{array}{r}
3.20 \\
40.80
\end{array}
$$$$
13.60
$$$$
18.00
$$

Above assays from samples South side vein 1300 down from top.

$$
\begin{aligned}
& 22 \\
& 0.16 \\
& 0.22 \\
& 3.20 \\
& \text { Above assays from samples south alden vein below } 1300 \mathrm{ft} \text {. } \\
& 25 \\
& 0.12 \\
& 2.40 \\
& 0.70 \\
& 14.00 \\
& 0.20 \\
& 4.00 \\
& 0.30 \\
& 6.00 \\
& \text {.... } \gamma^{\prime} \text { grazed by }
\end{aligned}
$$

collation assays were made when gad was was th 2000 per curse. 
$\therefore-\therefore \quad \ldots \quad a x 20.00$ ancomel

$\therefore$ noold King." Asoayo

Samplod kny 1832.

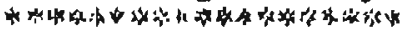

$\leftrightarrow$

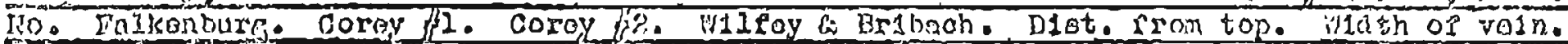

$\sum=1 \quad 30.40$

E-3 E03.20

$\mathrm{B}-\mathrm{A} \quad \mathrm{B} .00$

20.40

0.60

9.60

127.20

260.40

$D-3$

4.85

1.00

4.80

$B-7 \quad \therefore \quad 63.20$

12.00

12.80

36.00

36.00

$B-B$

D-9

7.20

112.00

211.00

8.80

0.10

B- -13

10.40

2.80
4.00

2.80

8.80

4.80

D-14

eraco.

10.00

- 80

E-15

2.60

$\because 7.480$
10.400

23.60

180.80

0.80

12.80

39.20

84.60

2.10

6.10

10.10

7.20

20.20

3.60

400 ?t.

$20 "$

26 Inchos.

$A-3$

$\Lambda=A$

$\Lambda-5$

$10.00 \quad \quad 0.60$

$A-6$

$\Lambda-7$

$\Lambda=0$

$A=2$

95.60

200.00

B. 60

6.30

7.80

6.80

2.80

2. 10

32.80

10.30

$0.20^{\circ}$

6.00

$\Lambda=11$

23.60

26.00

22.90

33.60

$A-13$

27.60

$20 . \leq 0$

$\Lambda-14$

3.60

$\$ .00$

57.60

24.10

$\Lambda-16$

$A=17$

21.20

24.00

6.40

6.80

8.40

8.80

14.80

14.80

$\Lambda=19$

3.20

3.20

40.80

26.00

$13.60 \div 13.20$

14.40

12.80

7.00

80.00

$\$ .80$

8.00

4.80

31.20

8.00

15.80

53.60

28.80

6.40

25.80

22.50

8.80

9.80

16.80

1.90

28.00

15.20

11.20

16.00

4.00

6.00

$520 \mathrm{n}$

650 o

$050 "$

$090 \%$

830 "

$2100 n$

$1200 \%$

$2.00 \%$

$260 "$

$300 \%$

I0 $\quad$ (Ant. onzy)

6.80

6.00

6.00

100

20
52.0
550

$350 \%$

$$
\begin{array}{ll}
29 & 17 \\
20 &
\end{array}
$$

2510

120

21 吉

$20 \pi$
16
$18 n$ (rooktant.) $25 \quad n \quad n \quad n$

$A-2 A$
$A-30$

$$
\text { . }
$$

.

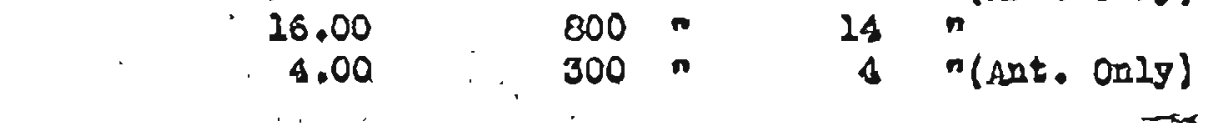

Rooso. starariog by

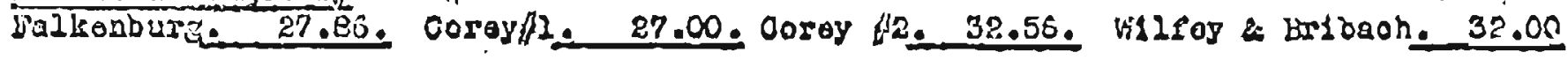

Sorery. averages by

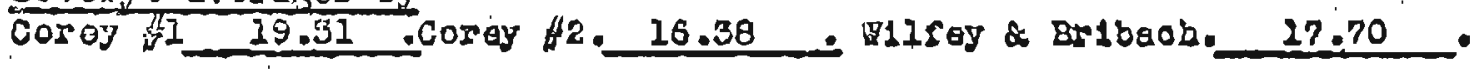

Composite aneays.

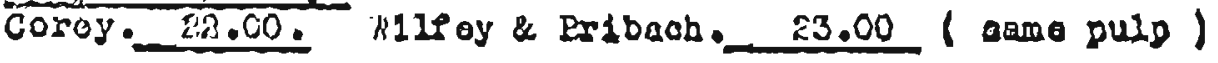

Ronso. averagne with sntimony stronk out

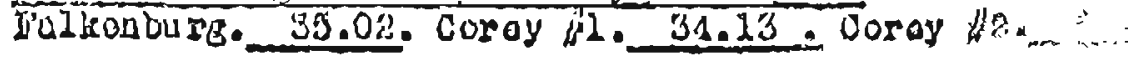

"ihath 10.60 . 